\title{
Rainfall and temperature attributes on the Lesotho- Drakensberg escarpment edge, southern Africa
}

\author{
Werner $\mathrm{Nel}^{1}$ and Paul Sumner ${ }^{2}$ \\ 1 Department of Geography and Environmental Science, University of Fort Hare, South \\ Africa \\ 2 Department of Geography, Geoinformatics and Meteorology, University of Pretoria, \\ South Africa
}

\begin{abstract}
Located near the south-eastern limit of Africa, the Lesotho-Drakensberg and associated escarpment is the highest range of African mountains south of the massifs in Tanzania. At the escarpment summit and on the adjacent high peaks, the climate is generally interpreted as marginal periglacial yet few data, specifically rainfall and temperature, exist on record at these altitudes. Climatic data from two temporary field stations on the escarpment edge, one of which is the highest rainfall station yet on record in southern Africa, provide contemporary surface-climate conditions. Mean annual rainfall recorded between 2001 and 2005 averages $767.8 \mathrm{~mm}$ at Sani Pass summit (three complete years), and $753.2 \mathrm{~mm}$ on Sentinel Peak (two complete years); these values are less than those recorded for the same period in the mountain foothills. Even though rainfall is slightly below long-term rainfall averages for the area due to a marginally dry spell, the data show that earlier estimates of between $1000 \mathrm{~mm}$ and 2000 $\mathrm{mm}$ rainfall per annum on the escarpment are too high. A measured mean air temperature of $5.8^{\circ} \mathrm{C}$ at Sani Pass, however, falls within the range estimated for the escarpment summit. Frost cycles in air and at the soil surface are frequent in winter, but absent in soil for summer, and no long-duration surface-soil freeze was measured. Temperatures thus confirm the marginal periglacial nature as postulated for previously, but precipitation data indicate a dryer environment than anticipated. Palaeoenvironmental scenarios, notably arguments for former glaciation based on extrapolations from somewhat exaggerated contemporary precipitation values, thus require re-consideration.
\end{abstract}

\section{Introduction}

The Drakensberg-Lesotho range is a part of the main escarpment of southern Africa and has the highest mountains in Africa south of Tanzania's Mount Kilimanjaro. The escarpment typically reaches altitudes above $2800 \mathrm{~m}$ on the border between the South African province of KwaZulu-Natal and the Kingdom of Lesotho. Here, frost action and associated microforms classify the area as marginal or sub-periglacial (Boelhouwers 1994). Set slightly back from the escarpment within Lesotho, the highest point, Thabana Ntlenyana, measures $3482 \mathrm{~m}$ a.s.l. while foothills to the east in Kwa- Zulu-Natal fall rapidly to below $1500 \mathrm{~m}$ a.s.l. beneath the escarpment. Recently declared a Trans- Frontier National Park, the area is a popular tourist destination and has been declared a World Heritage Site; it houses unique flora and fauna and as a watershed is a vital natural water source with catchment drainage to the east coast and back into the interior via Lesotho. Given the altitudes attained, the persistence of 
soil frost action in winter and the palaeoenvironmental signatures found from former cold periods (see Boelhouwers and Meiklejohn 2002), the setting is unique in Africa south of the equatorial region.

Two inter-basin transfer schemes, the Tugela- Vaal (TUVA) transfer tunnel and the international Lesotho Highlands Water Project (LHWP), have their upper catchments in the mountains and feed the dryer interior of South Africa. The major source of rainfall is from large-scale line thunderstorms and orographically induced storms in the summer (Tyson et al. 1976) while mid-latitude cold fronts affect KwaZulu-Natal annually, mainly during winter, bringing some precipitation. In the Drakensberg foothills, summer rainfall from November to March, accounts for $75 \%$ of the annual rainfall whilst the winter from May to August accounts for less than 10\% (Nel and Sumner 2006). The El Niño/Southern Oscillation influences the summer rainfall variability of the KwaZulu-Natal Drakensberg with a statistically significant correlation existing between summer rainfall in the Drakensberg and the contemporaneous as well as the lagged Southern Oscillation Index (W. Nel, unpublished data). Snowfalls occur on average eight times a year (Tyson et al. 1976), predominantly in the summit region, although the frequency could be underestimated since localized snowfalls are not taken into account (Boelhouwers and Meiklejohn 2002). Heavy snowfalls in the high altitude areas can remain for several weeks on the ground (Hanvey and Marker 1992) and recent observationsby the authors on the escarpment suggest a waterequivalent of less than $100 \mathrm{~mm}$ p.a. (Nel and Sumner 2005), but the contribution of snow to the water budget remains largely unknown.

Notwithstanding the State, public and scientific interest in the area, a paucity of rainfall and temperature data, especially at high altitude, exists. Temperatures in headwater catchments at and above the escarpment are derived either as extrapolations from lower altitudes below the escarpmentor from relatively short-duration field monitoring. Above $2600 \mathrm{~m}$ a.s.l. the environmental lapse rate is estimated to be between $2.6^{\circ} \mathrm{C} / \mathrm{km}$ and $3.0^{\circ} \mathrm{C} / \mathrm{km}$ (Grab 1997a) and mean annual air temperature (MAAT) above $2800 \mathrm{~m}$ is assumed to be in the region of $3^{\circ} \mathrm{C}$ to $7^{\circ} \mathrm{C}$ (Boelhouwers 1994; Grab 1997b, 2002). During winter the soil is disrupted by frost action (Boelhouwers and Meiklejohn 2002), the general intensity and penetration of which are uncertain (Sumner 2003), but appear limited to the upper $15 \mathrm{~cm}$ of soil. Given the marginal frost activity, the effect of climate warming on frost-related processes is unknown. Some contemporary ground surface temperature data and observations on freezing depths on the high points of the escarpment region have been recorded, but these are limited to two sites (Grab 1997a; Sumner 2003) over single winters. Significantly though, while the estimated MAAT range appears small, departures from these current values are often cited when substantiating palaeoclimates, particularly when debating conditions around the Last Glacial Maximum(see Boelhouwers and Meiklejohn 2002). Scenarios such as the presence or absence of permafrost become borderline when estimated temperature depressions are 5 to $6^{\circ} \mathrm{C}$ from current MAAT values (e.g. Grab 2002; Sumner 2003).

In addition to the paucity of temperature records, there are no contemporary rainfall values published from these altitudes. This is particularly remarkable given that the central and northern Drakensberg and adjacent Lesotho upper catchments feed two major basin transfer systems. Several rainfall measurements do, however, exist from the early and mid-1900s. Killick (1978) documents the mean annual precipitation (MAP) for Sani Pass (2865 m a.s.l.) on the southern Drakensberg escarpment as $995.8 \mathrm{~mm}$ based on data from the 1930s and also cites a MAP of $1609 \mathrm{~mm}$ on the escarpment in the central Drakensberg at an unknown station at the summit of Organ Pipes Pass (2927 m a.s.l.). Carter (1967), in an 
assessment of the rainfall of Lesotho, published data from a station $\mathrm{N}$ situated approximately $1.8 \mathrm{~km}$ west of the escarpment at an altitude of $3121 \mathrm{~m}$ a.s.l. Mean annual precipitation for this site was $1068 \mathrm{~mm}$ based on five years in the early 1960s. Schulze (1979) published data from Sani Pass and Cleft Peak, situated on the escarpment edge at $2880 \mathrm{~m}$ a.s.l., where rainfall was ecorded for an unspecified short duration, and the monthly data synthesized to 21 years. Mean annual precipitation from both stations is unknown but by extrapolation from lower altitude it is estimated that $250 \mathrm{~mm}$ of rain falls in January and annual rainfall exceeds 1800 mm (Schulze 1979), possibly even 2000 mm p.a. (Tyson et al. 1976).

According to values available in the literature, precipitation on the escarpment could range from less than $1000 \mathrm{~mm}$ p.a. to in excess of $2000 \mathrm{~mm}$ p.a. Many contemporary authors cite MAP well exceeding $1000 \mathrm{~mm}$ p.a when considering the area above the escarpment, especially when extrapolating for palaeoclimates using departures from current values (Boelhouwers 1988; Grab 1994, 1996). In particular the high values (MAP exceeding 1500 mm p.a.) are cited in favour of former glaciation (Grab 2002; Mills and Grab 2005) when precipitation for the region was considered to be $70 \%$ of current values (Partridge 1997) but would then still support snow accumulation. Alternatively, dryer conditions would favour periglaciation at high altitude (see Boelhouwers and Meiklejohn 2002; Sumner 2004). The debate, highlighted by Boelhouwers and Meiklejohn (2002), remains unresolved but to a large extent could be solved by current records upon which to base extrapolations. This study provides climatic data obtained since 2001 from two temporary field stations on the escarpment edge, one of which is the highest station yet on record in southern Africa. Although some data are missing in the continuum, the records provide the most recent surface-climate conditions at escarpment altitudes.

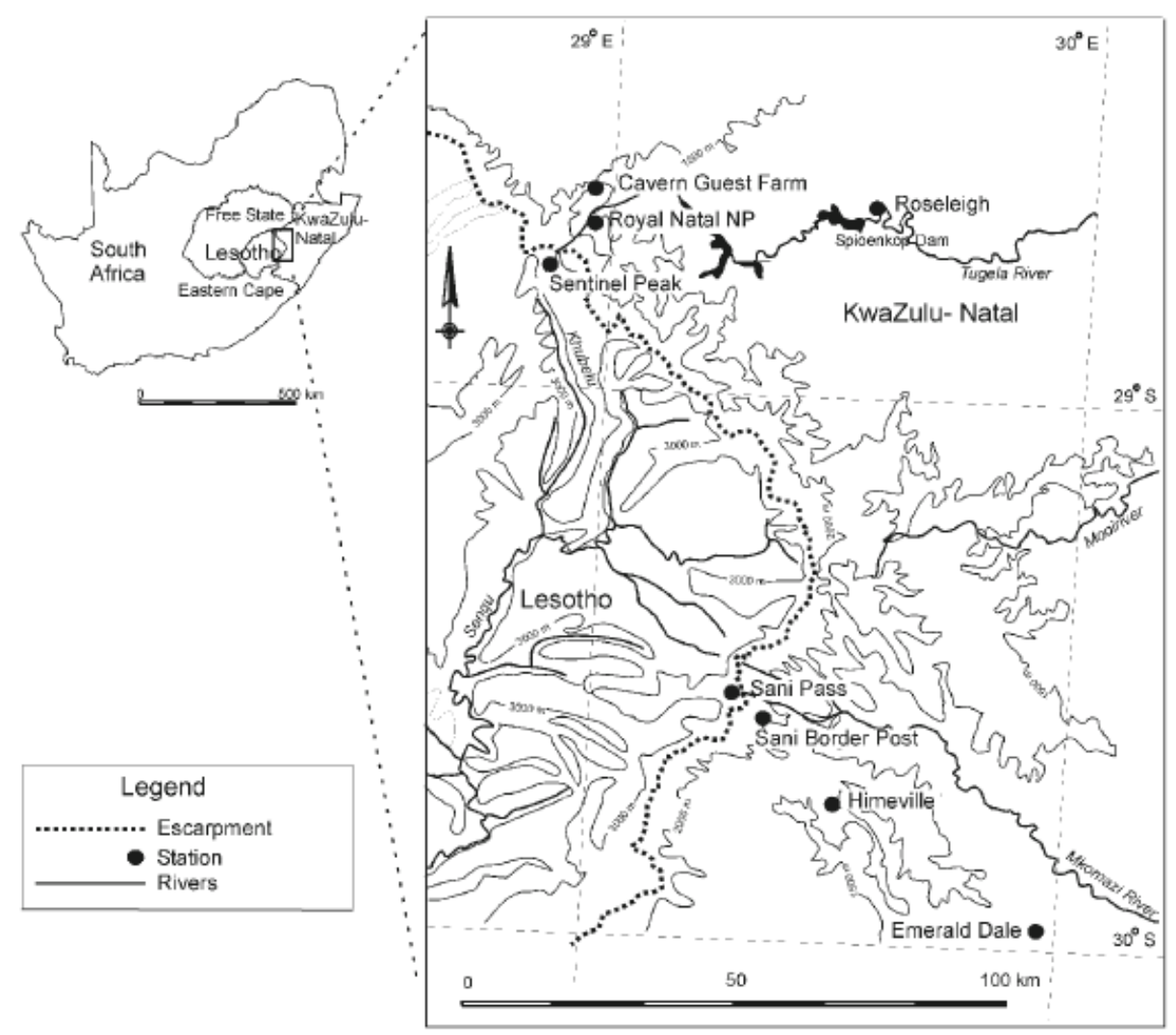


Fig.1. Map of the KwaZulu-Natal Drakensberg and the location of rainfall stations. The escarpment edge corresponds closely to the international border.

\section{Study sites and methodology}

This study focuses on rainfall, air temperature and soil temperature measurements recorded at two field stations. Climatic measurements on the escarpment are notably difficult due in part to inaccessibility but mainly because of equipment theft. Only one vehicle route climbs the escarpment in KwaZulu-Natal. Sani Pass is located in the southern Drakensberg, and a station was installed at the top of the pass on the escarpment edge adjacent to the tourist complex $\left(29.57^{\circ} \mathrm{S}, 29.27^{\circ} \mathrm{E}, 2850 \mathrm{~m}\right.$ a.s.l.) (Fig. 1). The second station was sited in the northern Drakensberg on the freestanding Sentinel Peak $\left(28.74^{\circ} \mathrm{S}, 28.89^{\circ} \mathrm{E}\right)$ and is the highest point where climatic attributes have been measured in southern Africa (3165 m) (Fig. 1). Although someof the early rainfall data were presented from the two sites (Nel and Sumner 2005), longer rainfall records and temperature data from the stations are presented here.

Rainfall was measured with a Davis-MC Systems (D-MCS) automated tipping-bucket raingauge. The D-MCS gauge has a $163 \mathrm{~mm}$ collection diameter, a tipping resolution of 0.2 $\mathrm{mm}$ and logs total rainfall every 5 minutes. For comparative purposes, monthly rainfall data from 1970 to 2005 were obtained from the South African Weather Service (SAWS) for stations at lower altitude (Fig. 1), namely Sani Pass Border Post, Himeville and Emerald Dale in the southern Drakensberg, and Royal Natal National Park, Cavern Guest Farm and Roseleigh in the northern Drakensberg (Table 1). Rainfall records recorded by the D-MCS are

deemed comparable against manual recording rain-gauges used by the SAWS (Nel and Sumner 2005). Air and soil temperatures were measured at both sites using an MC Systems two-channel logger. The air temperature sensor comprises of a $5 \mathrm{~mm}$ diameter thermocouple cased in stainless steel, while the soil temperature sensor, which was on acable extension, comprises a similar thermocouple but with a resin tip. At Sani Pass the air temperature sensor was placed in a Stevenson Screen and the soil temperature sensor inserted into a loamy soilsurface at $2.5 \mathrm{~cm}$ depth between grass tussocks. At Sentinel Peak air temperature was recorded at $1 \mathrm{~m}$ height in a radiation screen and the soil sensor was inserted into coarse gravel, with vegetation-free surface at $2.5 \mathrm{~cm}$ depth.

Table 1. Rainfall attributes at selected rainfall stations in the Drakensberg

\begin{tabular}{|c|c|c|c|c|c|c|c|}
\hline Rainfall Station & $\begin{array}{l}\text { Altitude } \\
\text { (m) }\end{array}$ & $\begin{array}{c}\text { Mean rainfall } \\
1970-2005 \\
(\mathrm{~mm})\end{array}$ & $\begin{array}{c}\text { Rainfall } \\
2002 \\
(\mathrm{~mm})\end{array}$ & $\begin{array}{c}\text { Rainfall } \\
2003 \\
(\mathrm{~mm})\end{array}$ & $\begin{array}{c}\text { Rainfall } \\
2004 \\
(\mathrm{~mm})\end{array}$ & $\begin{array}{c}\text { Rainfall } \\
2005 \\
(\mathrm{~mm})\end{array}$ & $\begin{array}{c}\text { Mean rainfall } \\
2002-2005 \\
(\mathrm{~mm})\end{array}$ \\
\hline \multicolumn{8}{|l|}{ Northern Drakensberg } \\
\hline Sentinel Peak & 3165 & - & - & 764.8 & $(417.2)$ & 741.6 & 753.2 \\
\hline Cavern Guest Farm & 1980 & 1317.2 & 1151.5 & 759.6 & 1349.9 & 1477.3 & 1184.6 \\
\hline Royal Natal National Park & 1392 & 1302.0 & 1281.2 & 774.1 & 1195.0 & 1260.8 & 1127.8 \\
\hline Roseleigh & 1219 & 807.6 & 635.0 & 387.5 & 764.5 & 944.5 & 682.9 \\
\hline \multicolumn{8}{|l|}{ Southern Drakensberg } \\
\hline Sani Pass & 2850 & - & 742.0 & - & 702.4 & 859.0 & 767.8 \\
\hline Sani Pass Border Post & 2055 & 1156.6 & 786.9 & 663.6 & 1051.5 & 928.9 & 857.7 \\
\hline Himeville & 1524 & 919.9 & 798.6 & 792.8 & 1249.0 & 607.3 & 861.9 \\
\hline Emerald Dale & 1189 & 852.0 & 902.2 & 526.6 & 945.5 & 797.6 & 793.0 \\
\hline
\end{tabular}


Table 2. Monthly rainfall (mm) measured at Sani Pass and Sentinel Peak

\begin{tabular}{|c|c|c|c|c|c|c|c|c|c|c|c|c|c|c|}
\hline Station & Year & Jan & Feb & Mar & Apr & May & Jun & Jul & Aug & Sep & Oct & Nov & Dec & Total \\
\hline \multirow[t]{5}{*}{ Sani Pass } & 2001 & & & & & & & & & & 100.6 & 141.0 & 101.8 & \\
\hline & 2002 & 79.4 & 51.0 & 114.8 & 28.6 & 24.4 & 8.8 & 24.2 & 37.2 & 54.2 & 60.0 & 61.6 & 197.8 & 742.0 \\
\hline & 2003 & 136.4 & 165.4 & 144.0 & 41.2 & \multicolumn{9}{|c|}{ No Data } \\
\hline & 2004 & 154.0 & 92.0 & 12.0 & 15.0 & 4.4 & 7.0 & 17.8 & 6.6 & 46.8 & 96.0 & 132.0 & 118.8 & 702.4 \\
\hline & 2005 & 172.4 & 132.8 & 144.2 & 50.2 & 6.6 & 10.8 & 0.2 & 26.0 & 28.0 & 98.8 & 113.8 & 75.2 & 859.0 \\
\hline \multicolumn{15}{|l|}{ Sentinel } \\
\hline \multirow[t]{4}{*}{ Peak } & 2002 & & & & & & & & & & & & 187.2 & \\
\hline & 2003 & 144.6 & 148.0 & 117.4 & 42.0 & 11.8 & 3.0 & 0.4 & 5.8 & 17.4 & 47.8 & 131.6 & 95.0 & 764.8 \\
\hline & 2004 & 71.0 & 0.0 & 0.2 & 17.2 & 2.6 & 0.2 & 15.8 & 8.6 & 30.6 & 62.2 & 97.0 & 111.8 & (417.2) \\
\hline & 2005 & 240.6 & 151.4 & 166.0 & 42.2 & 17.0 & 9.2 & 0.0 & 46.0 & 0.0 & 0.2 & 21.4 & 47.6 & 741.6 \\
\hline
\end{tabular}

Sani Pass rainfall monitoring commenced from October 2001. High wind speeds caused the logger support platform to be damaged in mid-2003 and records for that year are incomplete. Rainfall data presented here for Sani Pass are from October 2001 to April 2003 and from January 2004 to the end of December 2005. Air and soil temperature were recorded at hourly intervals from 1 November 2001 to 17 March 2002, and then at 2-hour intervals from 23 September 2002 to 10 July 2003. Thereafter, to reduce the number of visits, 6-hour averages were recorded from 9 January 2004 to 15 January 2005. On Sentinel Peak rainfall was recorded from 1 December 2002 to 31 December 2005. Temperature recordings on the peak were erratic due to repeated failure and replacement of the two-channel logger. The only temperature data that were available for direct comparison with Sani Pass are 1-hour recordings from 23 November 2001 to 17 March 2002.

\section{Findings}

\section{Rainfall totals}

Total rainfall recorded at Sani Pass during the calendar year 2002 was 742 mm. During 2004 rainfall totalled $702.4 \mathrm{~mm}$ and in 2005, $859 \mathrm{~mm}$ (Table 1). Mean over the three years was $767.8 \mathrm{~mm}$. Rainfall recorded during the January months of 2002, 2003, 2004 and 2005 was $79.4 \mathrm{~mm}, 136 \mathrm{~mm}, 154 \mathrm{~mm}$ and $172 \mathrm{~mm}$ respectively (Table 2). 

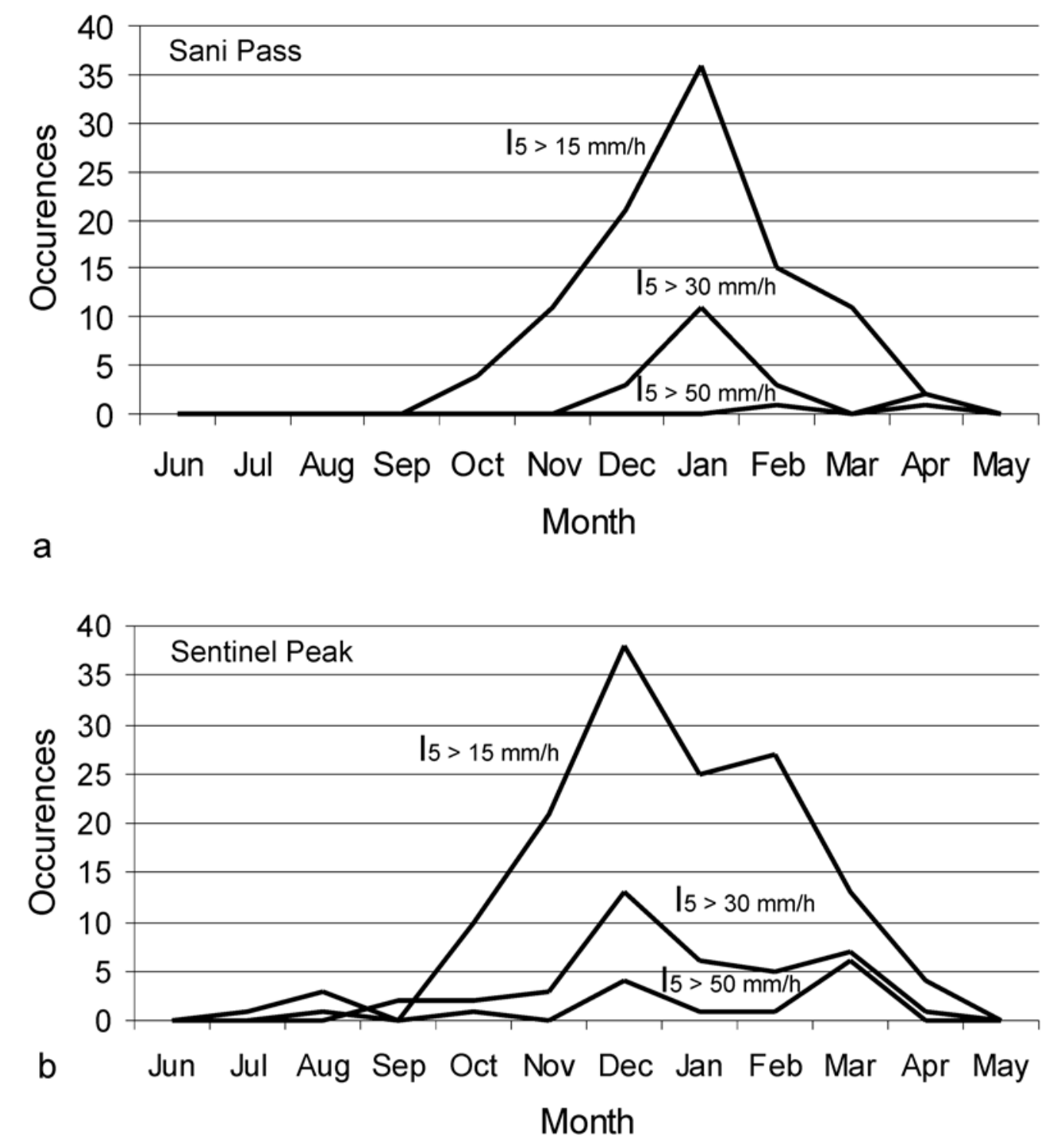

Fig. 2. Monthly occurrences of high intensity rainfall events at (a) Sani Pass and (b) Sentinel Peak

Summer rainfall total (November to March) for 2001/2002 was $488 \mathrm{~mm}$. During the summer of 2002/2003, $705 \mathrm{~mm}$ was recorded and rainfall during the 04/2005 summer season was 700 $\mathrm{mm}$. Winter rainfall (May to August) was considerably lower with $4.6 \mathrm{~mm}$ measured during 2002, $35.8 \mathrm{~mm}$ during 2004 and $43.6 \mathrm{~mm}$ measured during the winter of 2005 (Table 2). Total rainfall on Sentinel Peak for the calendar years 2003, 2004 and 2005 was $764.8 \mathrm{~mm}$, $417.2 \mathrm{~mm}$ and $741.6 \mathrm{~mm}$ respectively (Table 1). No rainfall was recorded at the Sentinel during February 2004, which is anomalous and could be due to equipment malfunction, but this could not be verified. Excluding 2004, the mean annual rainfall for 2003 and 2005 was $753.2 \mathrm{~mm}$. During the only directly comparable year, 2005 (Table 2), Sani Pass received $117.4 \mathrm{~mm}$ more rainfall than Sentinel Peak. 
Table 3. Number of rain days measured at Sani Pass and Sentinel Peak

\begin{tabular}{lcrrrrrrrrrrrrr}
\hline Station & Year & Jan & Feb & Mar & Apr & May & Jun & Jul & Aug & Sep & Oct & Nov & Dec & Total \\
\hline Sani Pass & 2001 & & & & & & & & & & & 14 & 18 & 17 \\
& 2002 & 21 & 9 & 15 & 6 & 7 & 5 & 6 & 10 & 13 & 12 & 14 & 23 & $\mathbf{1 4 1}$ \\
& 2003 & 19 & 16 & 12 & 9 & & & & No Data & & & & \\
& 2004 & 17 & 23 & 7 & 7 & 2 & 2 & 5 & 3 & 9 & 18 & 21 & 22 & $\mathbf{1 3 6}$ \\
& 2005 & 26 & 21 & 21 & 9 & 2 & 3 & 0 & 5 & 3 & 16 & 18 & 17 & $\mathbf{1 4 1}$ \\
Sentinel Peak & 2002 & & 21 & & & & & & & & & & & \\
& 2003 & 13 & 18 & 11 & 9 & 4 & 2 & 0 & 2 & 11 & 12 & 17 & 13 & $\mathbf{1 1 2}$ \\
& 2004 & 9 & 0 & 0 & 2 & 1 & 0 & 5 & 4 & 5 & 13 & 15 & 21 & $\mathbf{7 5}$ \\
& 2005 & 24 & 15 & 18 & 9 & 3 & 3 & 0 & 7 & 0 & 0 & 2 & 12 & $\mathbf{9 3}$ \\
\hline
\end{tabular}

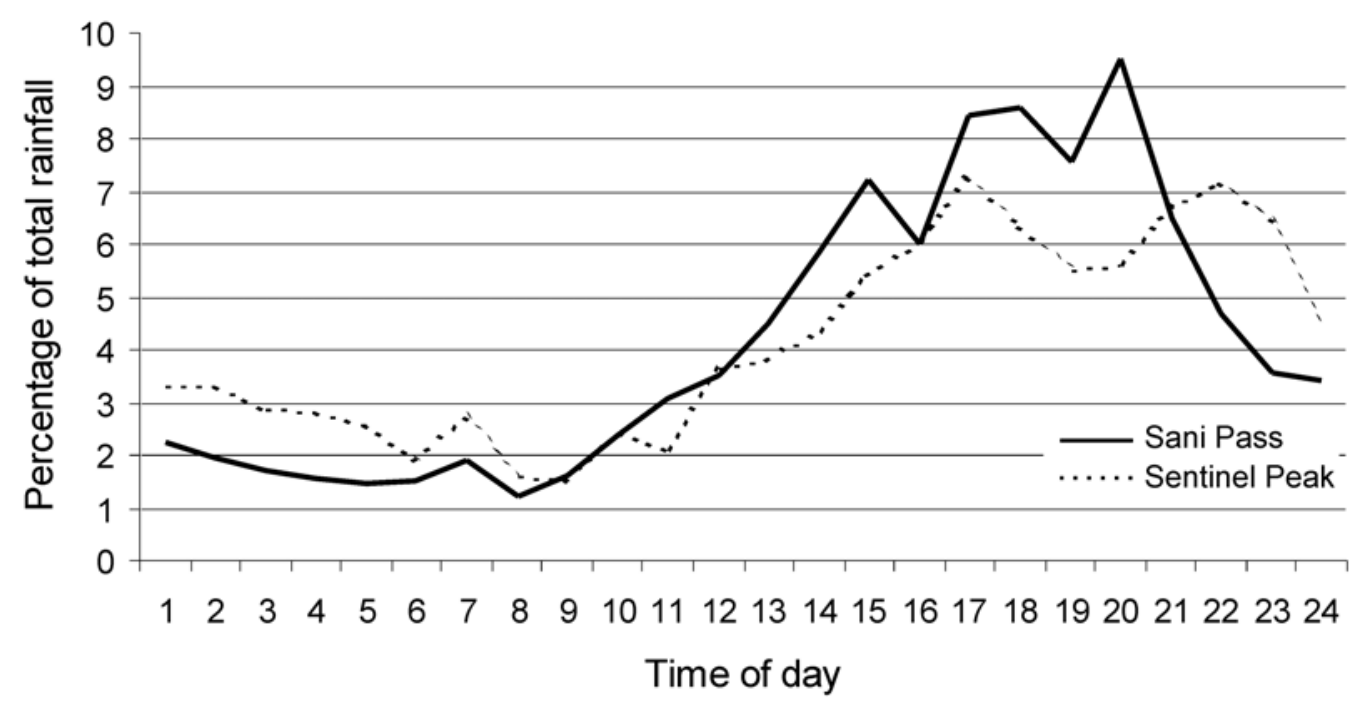

Fig. 3. Timing of daily rainfall on the Drakensberg escarpment edge

January rainfall recorded on Sentinel Peak during 2003, 2004 and 2005 was 145 mm, 71 mm and $241 \mathrm{~mm}$ respectively (Table 2). Summer rainfall totals (November to March) for 2002/2003 were 298 mm and for 2004/2005 were 767 mm. Winter rainfall (May to August) measured at Sentinel Peak was $21.0 \mathrm{~mm}$ measured during 2003, $27.2 \mathrm{~mm}$ in 2004 and 72.2 $\mathrm{mm}$ measured during the winter of 2005 (Table 2).

Rainfall intensity and rain days

A rain day is defined as one on which at least $0.5 \mathrm{~mm}$ of rainfall is measured (Schulze 1979). At Sani Pass the number of rain days in 2002 totalled 141 while the number of rain days in 2004 and 2005 was 136 and 141 respectively (Table 3). At the Sentinel fewer were recorded, with 112 days measured during 2003, 75 in 2004 and 93 during 2005 (Table 3). Monthly rain days also vary considerably, with the summer months (January, February, March, November and December) contributing between 58 and 73\% of the annual total measured at Sani Pass. At the Sentinel the number of rain days measured during summer constitutes between 60 and $76 \%$ of the annual total. 
Rainfall is the key process in water erosion through the detachment of soil particles and creation of surface runoff (Moore 1979) and in turn is related to the intensity at which this rain falls (Van Dijk et al. 2002). At both escarpment sites, five minute intensities (I5) were analysed and the number of occurrences of I5 more than the thresholds of $15 \mathrm{~mm} / \mathrm{h}, 30 \mathrm{~mm} / \mathrm{h}$ and $50 \mathrm{~mm} / \mathrm{h}$ were compared. Sani Pass recorded 142 occurrences of I5 more than $15 \mathrm{~mm} / \mathrm{h}$, 39 occurrences of I5 more than $30 \mathrm{~mm} / \mathrm{h}$ and 13 occurrences of I5 more than $50 \mathrm{~mm} / \mathrm{h}$. In comparison, Sentinel Peak recorded 100 occurrences of I5 more than $15 \mathrm{~mm} / \mathrm{h}, 19$ of more than $30 \mathrm{~mm} / \mathrm{h}$ and only 2 occurrences of $I 5$ more than $50 \mathrm{~mm} / \mathrm{h}$. The monthly distribution of high intensity events was also analysed (Fig. 2) and the highest number of occurrences of 5min rainfall intensity above $15 \mathrm{~mm} / \mathrm{h}$ and $30 \mathrm{~mm} / \mathrm{h}$ were measured in January at Sentinel Peak. At Sani Pass the most occurrences of 15 above $15 \mathrm{~mm} / \mathrm{h}$ and $30 \mathrm{~mm} / \mathrm{h}$ were measured in December and March.

Total hourly rainfall as a percentage of total rainfall was considered. At Sani Pass nearly $10 \%$ of the total rainfall measured falls between $19 \mathrm{~h} 00$ and $20 \mathrm{~h} 00$, and $60 \%$ of all rainfall is measured between $13 \mathrm{~h} 00$ and 21h00 (Fig. 3). At Sentinel Peak approximately 7\% of total rainfall was measured between $16 \mathrm{~h} 00$ and $17 \mathrm{~h} 00$ and between $21 \mathrm{~h} 00$ and 22h00, and approximately $61 \%$ between $13 \mathrm{~h} 00$ and 23h00 (Fig. 3).

\section{Air and soil temperatures}

A continuous record of soil and air temperatures was not possible due to regular failure coupled with tampering and theft of the sensors and loggers, which highlights the difficulty of monitoring in this setting. Sani Pass provided the most complete data on record spanning the summer of 2001 to the summer of 2005 (Table 4). Only one uninterrupted year-cycle of temperatures was recorded, from 10 January 2004 to 9 January 2005.

Table 4. Air and soil temperatures measured at Sani Pass

\begin{tabular}{lcccr}
\hline & $\begin{array}{c}\text { Summer 2001/2 } \\
\text { (1 Nov to 17Mar) }\end{array}$ & $\begin{array}{c}\text { Summer 2002/3 } \\
\text { (1 Nov to 31 Mar) }\end{array}$ & $\begin{array}{c}\text { Winter 2003 } \\
\text { (1 May to 10 Jul) }\end{array}$ & $\begin{array}{c}\text { Winter 2004 } \\
\text { (1 May to 31 Aug) }\end{array}$ \\
\hline Mean air Temp. & 6.7 & 6.6 & -2.9 & -2.1 \\
Mean soil Temp. & 11.9 & 10.6 & 1.5 & 0.7 \\
Min. air Temp. & -1.6 & -5.6 & -11.0 & -11.3 \\
Max. air Temp. & 20.8 & 21.0 & 13.2 & 12.2 \\
Min. soil Temp. & 4.0 & 1.4 & -2.1 & -3.0 \\
Max. soil Temp. Soil & 24.3 & 23.8 & 13.5 & 12.5 \\
No. of freezing cycles in air & 4 & 6 & 65 & 76 \\
No. of freezing cycles in soil & 0 & 0 & 40 & 48 \\
No. of frost days in air & 0 & 0 & 6 & 17 \\
No. of frost days in soil & 0 & 1 & 5 & 0 \\
\hline
\end{tabular}


Table 5. Air and soil temperatures measured at Sani Pass and Sentinel Peak (21/11/2001$17 / 3 / 2002)$

\begin{tabular}{|c|c|c|c|c|c|}
\hline Station & Statistic & $\begin{array}{l}\text { Daily Air } \\
\text { Temp. (") }\end{array}$ & $\begin{array}{l}\text { Daily Soil } \\
\text { Temp. }\left({ }^{\circ}\right)\end{array}$ & $\begin{array}{l}\text { Rate of change air } \\
\left.\text { Temp. ( }{ }^{\circ} \mathrm{C} / \text { hour }\right)\end{array}$ & $\begin{array}{l}\text { Rate of change soil } \\
\text { Temp. ('C/hour) }\end{array}$ \\
\hline Sani Pass & $\begin{array}{c}\text { Mean } \\
\text { Mean min. } \\
\text { Mean max. } \\
\text { Absolute min. } \\
\text { Absolute max. }\end{array}$ & $\begin{array}{r}9.7 \\
4.8 \\
14.6 \\
-1.6 \\
20.8\end{array}$ & $\begin{array}{r}14.1 \\
10.1 \\
18.9 \\
6.9 \\
24.3\end{array}$ & 0.9 & 0.7 \\
\hline Sentinel Peak & $\begin{array}{c}\text { Mean } \\
\text { Mean min. } \\
\text { Mean max. } \\
\text { Absolute min. } \\
\text { Absolute max. }\end{array}$ & $\begin{array}{r}9.3 \\
5.9 \\
13.5 \\
2 \\
18.8\end{array}$ & $\begin{array}{r}13.2 \\
6.1 \\
24.3 \\
1.3 \\
38.5\end{array}$ & 0.8 & 11.1 \\
\hline
\end{tabular}

Screened mean air temperature over this period was $5.8^{\circ} \mathrm{C}$ and mean soil surface temperature $8.5^{\circ} \mathrm{C}$. As expected, the numbers of freezing cycles and freezing days, where mean temperatures remain below zero, are dominant in the winter periods.

Minimum and maximum soil temperatures were consistently higher than the corresponding air temperatures in both winter and summer (Table 4). The minimum air temperature was $11.3^{\circ} \mathrm{C}$ recorded on 29 July 2004. In 2003, the winter minimum was similar at $-11.0^{\circ} \mathrm{C}$ on both mornings of 5 and 6 August. In contrast, soil surface temperatures only reached $-3.0^{\circ} \mathrm{C}$ and $-2.1^{\circ} \mathrm{C}$ minima in the respective winters. Diurnal freezing cycles were, however, frequent in winter, and the longest period of continuous soil freeze recorded was only four days.

Air and soil temperatures recorded hourly at Sani Pass and Sentinel Peak for the summer of 2001/2002 are compared in Table 5. At Sani Pass, mean air and soil temperatures for this period were $9.7^{\circ} \mathrm{C}$ and $14.1^{\circ} \mathrm{C}$, and at Sentinel Peak $9.3^{\circ} \mathrm{C}$ and $13.2^{\circ} \mathrm{C}$ respectively. Daily minima and maxima were considered (Table 5, Fig. 4); the mean daily minimum air temperature recorded at Sani Pass for this period was $4.8^{\circ} \mathrm{C}$, mean daily maximum air temperature was $14.6^{\circ} \mathrm{C}$, and absolute minimum and maximum were $-1.6^{\circ} \mathrm{C}$ and $20.8^{\circ} \mathrm{C}$. Mean daily minimum and maximum air temperatures recorded at Sentinel Peak for the same period were $5.9^{\circ} \mathrm{C}$ and $13.5^{\circ} \mathrm{C}$ and absolute minimum and maximum were $2^{\circ} \mathrm{C}$ and $18.8^{\circ} \mathrm{C}$. Mean daily minimum soil temperature for this period recorded at Sani Pass was $10.1^{\circ} \mathrm{C}$, and mean daily maximum air temperature was $18.9^{\circ} \mathrm{C}$. Absolute minimum and maximum soil temperatures measured at Sani were $6.9^{\circ} \mathrm{C}$ and $24.3^{\circ} \mathrm{C}$. Mean daily minimum and maximum soil temperatures during the same period at Sentinel Peak were $6.1^{\circ} \mathrm{C}$ and $24.3^{\circ} \mathrm{C}$, and absolute minimum and maximum soil temperatures were $1.3^{\circ} \mathrm{C}$ and $38.5^{\circ} \mathrm{C}$ respectively (Table 5).

\section{Discussion}

Rainfall totals from the two stations were considerably less than expected in comparison to earlier literature. Although the measured totals from the 1930s show a MAP slightly below $1000 \mathrm{~mm}$ (Killick 1978), all other measurements and extrapolations far exceed the totals measured here. 


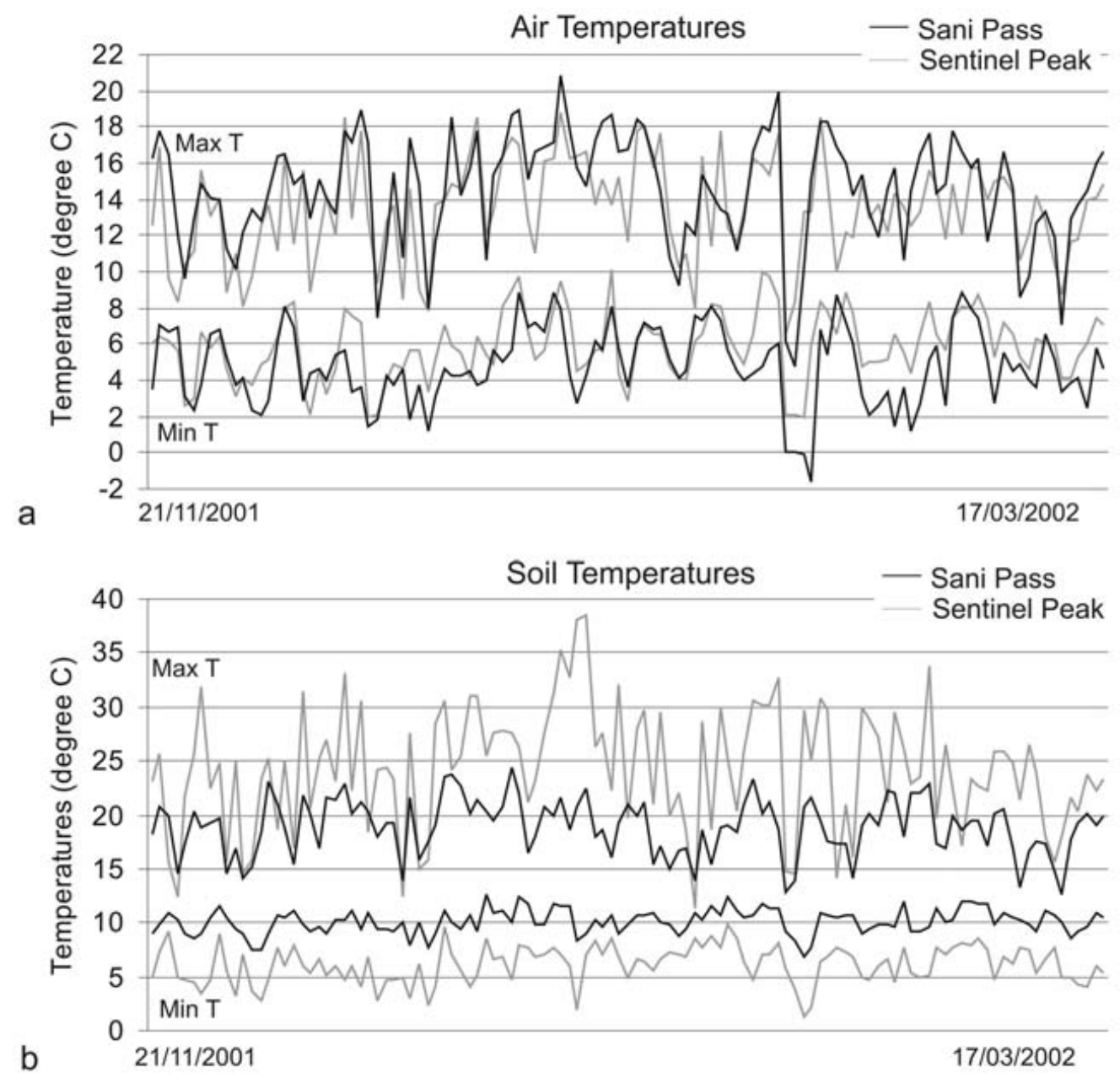

Fig. 4. Daily minimum and maximum temperatures measured at Sani Pass and Sentinel Peak for (a) air and (b) soil (21/11/2001-17/ 3/2002)

The monitoring period was, however, marginally dryer than long-term averages. In comparison to mean annual rainfall totals since 1970 (36 years) at six established stations, the period 2002 to 2005 had 85 to $90 \%$ of the mean annual rainfall in the northern Drakensberg and between 74 and 93\% of the mean annual rainfall in the southern Drakensberg. The mean rainfall for January $(135.5 \mathrm{~mm})$ for the top of Sani (four years) and $152 \mathrm{~mm}$ for Sentinel Peak (three years) as well as the annual rainfall measured at the top of Sani Pass in 2002, 2004 and 2005 (767.8 mm) and on Sentinel Peak in 2003 and 2005 (753.2 $\mathrm{mm}$ ) are thus probably slightly below longterm rainfall averages for the sites. Nonetheless, averages remain substantially less than anticipated. Either rainfall has been severely overestimated in the past or the sensitivity to dry and wet periods is far greater at higher altitudes. It is worth noting that the 1970s, a period where several of the estimates for rainfall were made (Tyson et al. 1976; Schulze 1979), was a wetter period in southern Africa (Tyson and Preston-Whyte 2000). Longer-term records may provide a solution but, given the data provided here, it is apparent that rainfall on the escarpment area may have 
been overestimated in the past. Extrapolation towards palaeoprecipitation scenarios using values exceeding $1000 \mathrm{~mm}$ p.a. should thus be made with caution.

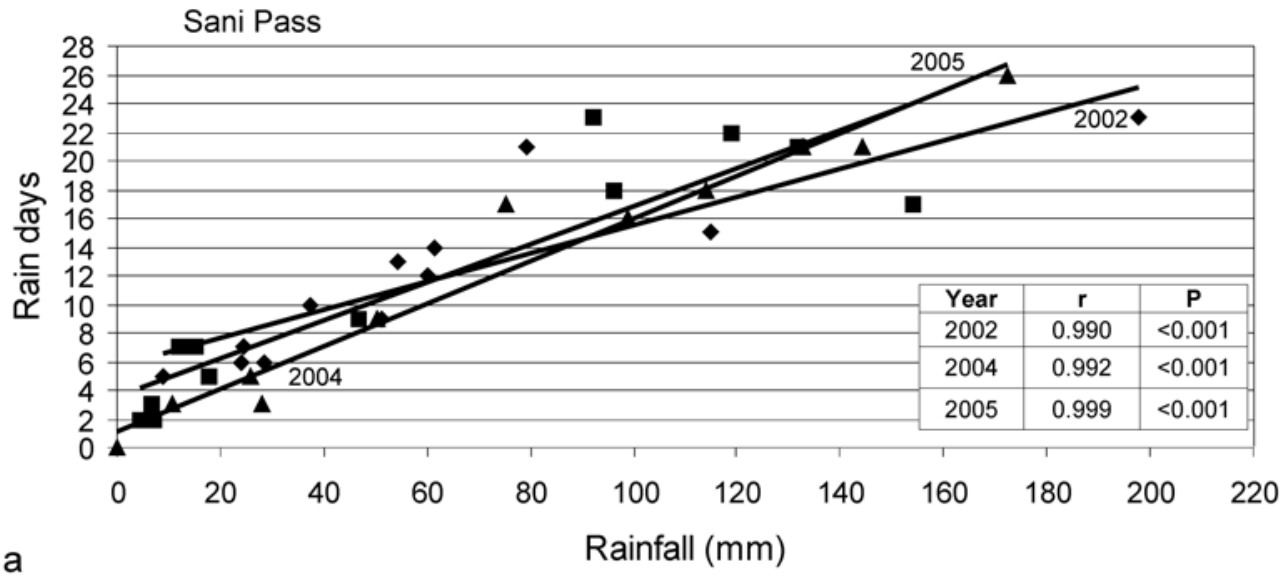

a

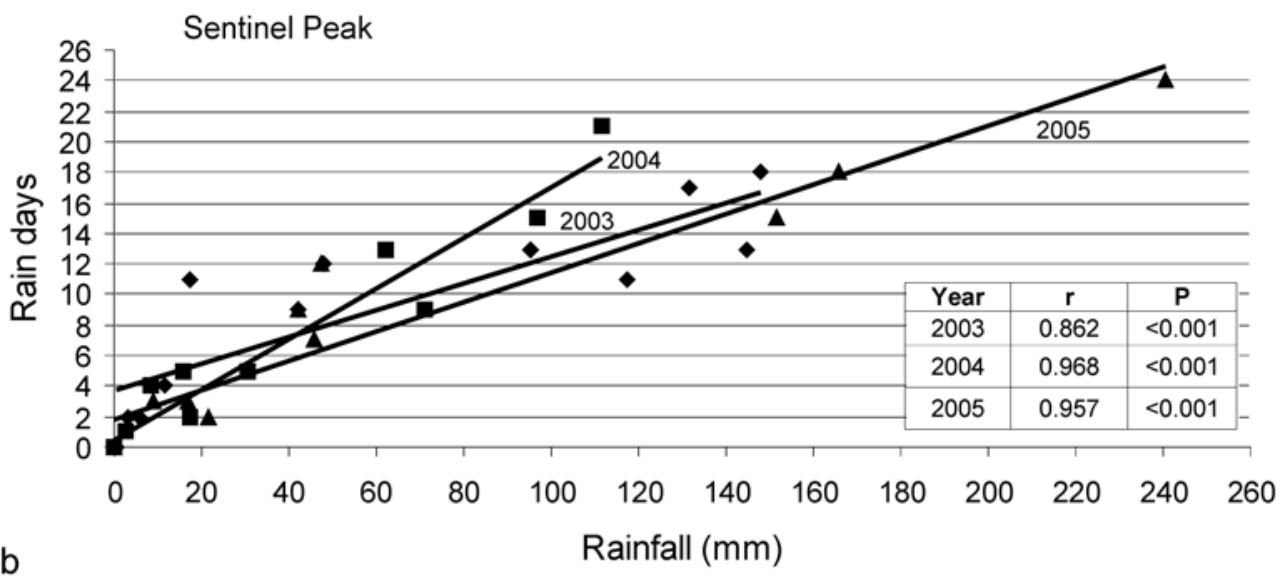

Fig. 5. Correlation between monthly rainfall and rain days for (a) Sani Pass and (b) Sentinel Peak

With respect to rain days, in both the southern and northern Drakensberg the number of rain days increased slightly with altitude (Nel and Sumner 2005) and the number of rain days measured each month at the two stations is strongly correlated with the respective monthly rainfall and the linear relationship is statistically significant at $\mathrm{P}<0.001$ (Fig. 5). As expected, an increase in measured monthly rainfall signifies an increase in the number of rain days for that particular month. Schulze (1979, Fig. 4.11, p. 66) estimates that the Drakensberg escarpment receives approximately 125 rain days a year. Rain days measured here indicate that the southern Drakensberg receives more than the estimate, and the north fewer rain days, but as a regional figure for the whole escarpment edge 125 rain days appears to be a good approximation. Even though the correlation coefficients between monthly rainfall and rain days measured at the two stations are similar, differences in the amount of rainfall and the number of rain days that exist between the two stations are considered further. At Sani Pass the amount of rainfall measured in 2002 is $742 \mathrm{~mm}$ and it was recorded in 141 days, 
representing a mean of $5.3 \mathrm{~mm}$ per rain day. At Sentinel Peak in 2005 the same amount of rainfall $(741.6 \mathrm{~mm}$ ) only fell in 93 days, which gives $7.8 \mathrm{~mm}$ per rain day. For the same year (2005) Sani Pass received $6.1 \mathrm{~mm}$ per rain day in 141 days. Based on these data it thus seems that on the northern Drakensberg escarpment fewer rain days can be expected.

With respect to erosive events, in the southern Drakensberg the monthly distribution of high intensity 5-min rainfall is more complex than in the north, with the most occurrences easured during December and March. Most rainfall events in the high Drakensberg occur in the late afternoon/early evening, with Sani Pass and the Sentinel showing 40.1\% and 30.8\% of total rainfall measured between the hours of $15 \mathrm{~h} 00$ and $20 \mathrm{~h} 00$ respectively. This is an indication of convective precipitation when sufficient cooling has occurred for condensation and cloud formation. This correlates well with Tyson et al. (1976) who suggest that the major source of rainfall is from large-scale line thunderstorms and orographically induced storms, and Schulze (1965) who indicates that thunderstorms in the Drakensberg occur in mid- to late afternoon.

Temperature records from Sani Pass proved to be intermittent and highlight the problems associated with attempts at monitoring along the escarpment edge. Only one complete annual cycle of records was made, in 2004, but several summer and winter periods are on record. In that year the mean air temperature of $5.8^{\circ} \mathrm{C}$ falls within the range estimated for above the escarpment (see Boelhouwers 1994), but is somewhat higher than the $3^{\circ} \mathrm{C}$ to $4^{\circ} \mathrm{C}$ MAAT postulated by, for example, Grab $(1994,1997 b)$ on the plateau peaks immediately behind the escarpment. As expected, frost cycles in air and soil surface are frequent in winter, but absent in soil for summer, although a few are recorded in air in summer. In general the soil temperatures are higher than air temperature and thus air temperature cannot be realistically used as a surrogate to analyse soil frost phenomena. Even though the minimum soil temperatures measured at Sani Pass were $-2.1^{\circ} \mathrm{C}$ and $-3^{\circ} \mathrm{C}$ for the winters of 2003 and 2004 respectively, no long-duration, or seasonal, freeze was found for the soil surface in either of the winters on record. In contrast, a seasonal freeze of 56 days was found at $2 \mathrm{~cm}$ depth at $3200 \mathrm{~m}$, some $300 \mathrm{~m}$ higher in altitude near Thabana Ntlenyana to the north of Sani Pass, with a winter minimum of $-4.5^{\circ} \mathrm{C}$ reached (Sumner 2003). Although the records represent separate winters, the difference may highlight the role of increasing altitude above the escarpment in depressing soil temperatures. At lower altitudes, few recent soil-air temperature data sets exist for comparison with the data provided here. In the Central Drakensberg at $1920 \mathrm{~m}$ a.s.l. Sumner and Nel (2006) recorded air and soil surface minimum temperatures of $-3.3^{\circ} \mathrm{C}$ and $0.6^{\circ} \mathrm{C}$, and mean air and soil temperatures of $4.3^{\circ} \mathrm{C}$ and $4.2^{\circ} \mathrm{C}$ respectively over the winter of 2001. During the winters of 2003 and 2004, mean air and soil temperatures recorded at Sani Pass were $-2.9^{\circ} \mathrm{C}$ and $1.5^{\circ} \mathrm{C}$, and $-2.1^{\circ} \mathrm{C}$ and $0.7^{\circ} \mathrm{C}$ respectively. Based somewhat speculatively on these data, it seems that air temperature decreases more rapidly than soil temperature with altitude, thus highlighting the difficulty in extrapolating soil conditions through air temperatures.

Comparing air and soil temperature data at the two escarpment sites it is clear that differences exist with regards to minimum and maximum soil temperatures. As noted above, the soil temperature sensor at Sani Pass was inserted into a loamy soil surface between grass tussocks, and at Sentinel Peak the sensor was inserted into a dark coarse gravel surface with no vegetation cover. Even though mean daily soil temperatures for the period are similar, differences in absolute minimum and maximum soil temperatures, as well as the temperature range between Sentinel Peak and Sani Pass, appear related to the type or texture of soil and differences in vegetation cover. At Sani Pass, where the sensor was in soil with vegetation 
cover, the range between minimum and maximum temperature and the rate of temperature change is less than in the coarse Sentinel material, which has a larger temperature range, a faster rate of temperature change and reaches higher and lower maximum and minimum temperatures (Table 5). Sumner and Nel (2006) also highlight the role of vegetation cover as an inhibitor to soil frost. Given the changes anticipated with climatic change (e.g. Rautenbach et al. 2005) or associated with intensified land use, the role of vegetation may be even more significant in inhibiting soil movement or degradation associated with frost action (see Boelhouwers and Meiklejohn 2002) than previously considered.

\section{Summary}

Weather station data from two sites on the Drakensberg- Lesotho escarpment provide new contemporary surface-climatic data from this unique setting in Africa. Rainfall, collected over a four-year period, shows lower totals than equivalent sites below the escarpment. Comparing mean annual rainfall totals from established stations in the foothills since 1970, the period 2002 to 2005 was slightly dryer than normal. Even though wind catch deficiency may exist to some extent (Nel and Sumner 2005) and the rainfall measured at the top of Sani Pass and Sentinel Peak is probably slightly below long-term rainfall averages for the sites, the data suggest that earlier estimates for total annual rainfall between $1800 \mathrm{~mm}$ and $2000 \mathrm{~mm}$ at the escarpment appear to be too high. Linked to this, the data thus also signify that it is unlikely an increase in rainfall with altitude exists all the way up to the escarpment (e.g. Tyson et al. 1976; Schulze 1979).

The mean air temperature measured at Sani Pass falls within the range estimated for the escarpment, but is somewhat higher than the $3^{\circ} \mathrm{C}$ to $4^{\circ} \mathrm{C}$ MAAT postulated for the plateau peaks immediately behind the escarpment (Grab 1994, 1997b). Frost cycles in air and soil surface are frequent in winter, but absent in soil for summer, although a few are recorded in air in summer. No long-duration or seasonal freeze was found for the soil surface, and in general the soil temperatures are higher than air tempertaures and thus air temperature cannot be realistically used as a surrogate to study soil frost. Comparing across the escarpment, no difference exists with regards to mean air and soil temperatures at the two stations, although temperature range differences appear related to the soil characteristics and vegetation cover. Rainfall totals are similar, but the amount of rainfall measured on each rain day is found to be proportionately more in the north than in the south. When comparing temperature data with those at slightly higher (Sumner 2003) and lower altitudes (Sumner and Nel 2006) it appears that air temperature decreases more rapidly with altitude than soil temperature. A strong decline in soil temperature may exist behind the escarpment onto the highest peaks but more field data are required to verify this.

Temperature findings, although limited in duration, support the classification of the Drakensberg- Lesotho summit area as currently marginal periglacial. Effects of global warming and land-use change, such as increased grazing, on frost action and land degradation (Boelhowers and Meiklejohn 2002) still require further exploration, but indications are that soil frost would be enhanced under a declining grass cover (see Sumner and Nel 2006). The dryer than anticipated current environment above the escarpment questions the accuracy of relief- based models from which former rainfall totals were generated. In addition, palaeoenvironmental extrapolation based on inflated current values, such as used in support of former glaciation, requires reconsideration. 


\section{References}

Boelhouwers, J.C., 1988: Geomorphological mapping of a part of the Giant's Castle Game Reserve, Natal Drakensberg. MSc dissertation. University of Natal.

Boelhouwers, J.C., 1994: Periglacial landforms at Giant's Castle, Natal Drakensberg, South Africa. Permafrost and Periglacial Processes, 5: 129-136.

Boelhouwers, J.C. and Meiklejohn K.I., 2002: Quaternary periglacialand glacial geomorphology of southern Africa: a review and synthesis. South African Journal of Science, 98: 47- 55 .

Carter, C.A., 1967: A survey of the surface water resources of the Upper Orange catchment. MSc (Eng) thesis. University of the Witwatersrand, Johannesburg.

Grab, S.W., 1994: Thufur in the Mohlesi Valley, Lesotho, southern Africa. Permafrost and Periglacial Processes, 5: 111- 118.

Grab, S.W., 1996: Debris deposits in the high Drakensberg, South Africa: possible indicators for plateau, niche and cirque glaciation. Zeitschrift für Geomorphologie, 103: 389-403.

Grab, S.W., 1997a. Analysis and characteristics of high altitude air temperature data from northern Lesotho: Implictions for cryogeomorphic occurrences. Geoökoplus, 4: 109-118.

Grab, S.W. 1997b: Thermal regime for a thufa apex and its adjoinind depression, Mashai Valley, Lesotho. Permafrost and Periglacial Processes, 8: 437-445.

Grab, S.W. 2002: Characteristics and paleaoenvironmental significance of relict sorted patterned ground, Drakensberg plateau, southern Africa. Quaternary Science Reviews, 21: 1729-1744.

Hanvey, P.M and Marker, M.E., 1992. Present-day periglacial micro- forms in the Lesotho highlands: implications for past climatic conditions. Permafrost and Periglacial Processes, 3: 353-361.

Killick, D.J.B., 1978: Further data on the climate of the Alpine Vegetation Belt of the eastern Lesotho. Bothalia, 12: 567- 572.

Mills, S.C. and Grab, S.W., 2005: Debris ridges along the southern Drakensberg escarpment as evidence for Quaternary glaciation in southern Africa. Quaternary International, 129: 6173.

Moore, T.R., 1979: Rainfall erosivity in East Africa. Geografiska Annaler, 61A: 147-156.

Nel, W. and Sumner, P.D., 2005: First rainfall data from the KZN Drakensberg escarpment edge (2002 and 2003). Water SA, 31: 399-402. 
Nel, W. and Sumner, P.D., 2006: Trends in rainfall total and variability (1970-2000) along the KwaZulu-Natal Drakensberg foothills. South African Geographical Journal, 88: 130137.

Partridge, T.C., 1997: Cainozoic environmental change in southern Africa, with special emphasis on the last 200000 years. Progress in Physical Geography, 21: 3-22.

Rautenbach, C.J. de W., Engelbrecht, F.A., Ndarana, T., Engelbrecht, C.J. and McGregor, J.L., 2005: Regional Model Development for Simulating Atmospheric Behaviour and Rainfall over Southern Africa. Water Research Commission Report, No. 1261/1/05.

Schulze, B.R., 1965: Hail and thunderstorm frequency in South Africa. Notos, 14: 67-71.

Schulze, R.E., 1979: Hydrology and Water Resources of the Drakensberg. Natal Town and Regional Planning Commission. Pietermaritzburg. Sumner, P.D., 2003: A contemporary winter ground thermal profile in the Lesotho Highlands and implications for active and relict soil frost phenomena. Earth Surface Processes and Landforms, 28: 1451-1458.

Sumner, P.D., 2004: Geomorphic and climatic implications of relict openwork block accumulations near Thabana-Ntlenyana, Lesotho. Geografiska Annaler, 86A: 181-194.

Sumner, P.D. and Nel, W., 2006: Surface-climate attributes at Injisuthi Outpost, Drakensberg, and possible ramifications for weathering. Earth Surface Processes and Landforms, 31: 1445-1451.

Tyson, P.D. and Preston-Whyte, R.A., 2000: The Weather and Climate of Southern Africa. Oxford University Press. Cape Town.

Tyson, P.D., Preston-Whyte, R.A. and Schulze, R.E., 1976: The climate of the Drakensberg. Natal Town and Regional Planning Commission. Pietermaritzburg.

Van Dijk, A., Bruijnzeel, L. and Rosewell, C., 2002: Rainfall intensity- kinetic energy relationships: a critical literature appraisal. Journal of Hydrology, 261: 1-23.

Manuscript received May 2007, revised and accepted June 2007. 